dosage is reached as a rule in 2-3 months. As in all "desensitization" procedures, it is inevitable that the state of hyposensitization attained will in due course be lowered if not lost. It is for this reason that maintenance doses as described should be continued for as long as thought necessary, especially in bee-keepers and others who cannot avoid contact with bees.

\section{Results of Desensitization}

A description has been given (Ordman, 1951) of three persons sensitive to bee stings in whom effective desensitization had been achieved with the use of whole-bee extract administered intracutaneously. Since that time 19 further instances of successful desensitization by this method have come to notice, bringing the total to 22 . These 19 cases have emerged from a study of 47 satisfactorily completed reports by physicians who had submitted their bee-stingsensitive patients to adequate desensitization. In 23 instances the patients had not been further stung by bees, and it is in the remaining 24 , where stinging had followed desensitization, that these 19 persons were found to be fully protected (see Table).

It may seem surprising that only 22 authenticated instances of successful desensitization can be quoted when material for prophylactic desensitization had been supplied over the years for some hundreds of persons. The explanation is, firstly, that most people subjected to bee stings in South Africa live in the rural areas and information about them must be obtained by correspondence with their doctors, leading all too often to little or no details about their patients in spite of follow-up letters. Secondly, in the bulk of the replies that do become available the information is vouchsafed that, although the patients had been properly desensitized according to our instructions, they had not subsequently been stung by bees.

Details are given in the Table of the 24 cases which had been submitted to desensitization and about which full reports were obtained. Effects of bee stings before and after such desensitization, results of skin-sensitivity tests, and the desensitization procedure itself are described for each case.

It will be observed that in 19 of these cases (1-19) the results were highly satisfactory, as no reactions, or very mild reactions only, were now occurring in persons who were originally very severely affected by bee stings. In Case 20 "some improvement" only was claimed. In Cases $21,22,23$, and 24 it was reported that desensitization procedures had produced no benefit at all-that is, reactions after bee stings were now as severe as they had been previously.

Cases 21, 22, 23.-These patients were highly sensitive by skin test to whole-bee extract (10 units). Desensitization was carried out to only 100 units or less instead of to the required $3,000-4,000$ units. Desensitization in each of these cases was obviously inadequate, and satisfactory results could not be expected.

Case 24.-For some reason this patient does not appear to have been highly skin-sensitive to whole-bee extract (1,000 units) by test, and desensitization should have gone on with strengths up to 4,000 units or even higher.

It becomes clear from the study of the Table that desensitization with whole-bee extract by the intracutaneous method is a very satisfactory procedure if properly carried out.

\section{Summary and Conclusions}

A procedure is described for the prophylactic desensitization of persons sensitive to bee stings by the use of increasing strengths of whole-bee extract administered intracutaneously.

A preliminary intracutaneous skin test is performed to determine the degree of the patient's sensitivity to the extract that is to be used for subsequent desensitization.

Successful desensitization is reported of 19 persons originally highly sensitive to bee stings.

\section{THE POLYSACCHARIDE BEHAVIOUR OF CANCER ANTIGENS}

\author{
BY
}

JACK G. MAKARI, M.D., D.T.M.\&H., Sc.M.

Research Department, Muhlenberg Hospital, Plainfield, New Jersey, U.S.A.

The high degree of accuracy in the detection of antigens in the sera of patients with carcinoma obtained by use of the Schultz-Dale method has already been reported (Makari, 1955a, 1955b). Recently Burrows (1958) confirmed these results in a thorough investigation of the test. The chemical nature of cancer antigens remains an unsolved problem. However, in studying hosttumour relationships it is extremely important to know the exact nature of these cancer antigens. In an effort to elucidate this problem, Burrows and Neill (1958) have investigated the nature of the immunologically active constituent of serum of patients with carcinoma. They attribute the antigenic activity of such sera in the Schultz-Dale test to the presence of a polypeptide.

The following application of the Schultz-Dale method leads us to believe that cancer antigens behave like polysaccharides and that the activity observed by Burrows and Neill in the polypeptide of the serum is probably due to an associated polysaccharide antigen.

\section{Methods}

Details of the Schultz-Dale method, the preparation of antigens, and the testing procedure have been described (Makari, 1955b). Tumour and normal tissues are homogenized in $0.2 \mathrm{~N}$ saline solution (one part of tissue plus four parts of saline) with a Sorvell homogenizer immersed in cracked ice. This procedure is allowed to continue for 10 minutes with the rheostat set at 115 . The homogenate is then centrifuged twice at 3,000 r.p.m. at $5^{\circ} \mathrm{C}$. for 10 minutes. The sediment is discarded and the supernatant is further centrifuged for 30 minutes at 10,000 r.p.m. at the same temperature. This sediment is separated and resuspended up to volume with normal saline solution. It is to be noted that this sediment differs from that used in my earlier work (Makari, 1955a, 1955b) in that the latter was obtained between 3,200 and 4,000 r.p.m. The sediment used in the present study - that is, that obtained between 3,000 and 10,000 r.p.m. - was chosen because it was found to have antigens in common with various tumours (Makari, 1958a).

The resuspended sediment and its supernatant comprise the antigens used in this study. They are used both in this form and after treatment by a procedure described by Chang (1953) and Chang, Snyder, and Murray (1953) in their preparation of an erythrocyte-sensitizing substance from rickettsial antigen which was thought to be polysaccharide in nature. In this procedure an equal volume of ether is added, with vigorous shaking for five minutes. It is then left undisturbed, to allow separation into ether and aqueous phases. The aqueous phase is mixed with alkali in the following proportion: nine volumes of the aqueous phase to one volume of $2 \mathrm{~N} \mathrm{NaOH}$. The mixture is kept in a water-bath at $100^{\circ} \mathrm{C}$. for 30 minutes. It is cooled and dialysed for two hours at 0 to $4^{\circ} \mathrm{C}$. against several changes of isotonic phosphate saline solution $\left(\mathrm{Na}_{2} \mathrm{HPO}_{4}, 0.81 \mathrm{~g}\right.$. ; $\mathrm{KH}_{2} \mathrm{PO}_{4}, 1.04$ g. ; NaCl, 6.8 g. ; distilled $\mathrm{H}_{2} \mathrm{O}, 1,000 \mathrm{ml}$.; $p \mathrm{H}=6.8$ ). The active material found inside the dialysis bag is then shaken with an equal volume of chloroform for 20 minutes and centrifuged at 2,000 r.p.m. for 15 minutes. In this study the chloroform layer is discarded and the clear aqueous phase containing the sensitizing substances (which are referred to as S.S.) is used. These behave as polysaccharides, being non-dialysable, resistant to boiling and alkalis, and giving a positive Molisch test. 
In an effort further to evaluate the polysaccharide nature of cancer antigens another method was used which is very similar to that described for the preparation of pneumococcal polysaccharides (Whistler and Smart, 1953).

In this method, melanoma antigen (fraction $O$ ), in equal amounts, is added to $95 \%$ ethanol chilled at $0^{\circ} \mathrm{C}$. This is centrifuged and the supernatant discarded. The sediment is suspended in $80 \mathrm{ml}$. of acetate buffer $(157.5 \mathrm{~g}$. of $\mathrm{NaC}_{2} \mathrm{H}_{3} \mathrm{O}_{2} .3 \mathrm{H}_{2} \mathrm{O}$ in three litres of distilled water and the $p \mathrm{H}$ adjusted to 6.05 with glacial acetic acid). This is then ground slowly at $0^{\circ} \mathrm{C}$. and centrifuged.

From the supernatant, the polysaccharide (fraction A) is precipitated by the addition of 5 volumes of cold isopropyl alcohol. The residue from the first grinding is again suspended in $80 \mathrm{ml}$. of acetate buffer and ground at $0^{\circ} \mathrm{C}$. The suspension is centrifuged and the supernatant precipitated with isopropyl alcohol (fraction B).
Fraction $\mathbf{A}$ is removed by centrifugation and dissolved in $100 \mathrm{ml}$. of cold distilled water. The resulting turbid greenish solution is deproteinized by the Sevag method in which $50 \mathrm{ml}$. of chloroform is added in $10 \mathrm{ml}$. of butyl alcohol for each $150 \mathrm{ml}$. of solution, and agitated from time to time in a homogenizer at $3^{\circ} \mathrm{C}$.

The resulting emulsion is centrifuged, and the aqueous layer centaining polysaccharide is separated. The aqueous layer is then adjusted to a concentration of $3 \%$ sodium acetate with saturated sodium acetate solution brought to pH 6 with acetic acid.

One half-volume of cold isopropyl alcohol is added to precipitate the polysaccharide, and the suspension is left overnight. The Sevag procedure is repeated until the material is completely deproteinized, after which the polysaccharide is centrifuged. This polysaccharide-like substance is referred to as P.L.S.

TABle I.-Parallel Behaviour by the Schultz-Dale Method, of Guinea-pig Uterine Horns Immunized Against Tissue Antigens and Their Corresponding Polysaccharide S.S.

\begin{tabular}{|c|c|c|c|c|c|c|c|c|c|c|}
\hline \multirow{2}{*}{$\begin{array}{c}\text { Reac- } \\
\text { tion } \\
\text { No. }\end{array}$} & \multicolumn{3}{|l|}{ Reaction Roleasod By } & \multicolumn{2}{|c|}{$\begin{array}{l}\text { Guinoa-pigs } \\
\text { Immunized } \\
\text { With S.S. }\end{array}$} & \multirow{2}{*}{$\begin{array}{l}\text { Reac- } \\
\text { tion } \\
\text { No. }\end{array}$} & \multicolumn{2}{|l|}{ Releasing Antigon } & \multicolumn{2}{|c|}{$\begin{array}{l}\text { Guinea-pigs } \\
\text { Immunized } \\
\text { With Antigen }\end{array}$} \\
\hline & Typo & & Amount & $\begin{array}{l}\text { Normal } \\
\text { Colon, } \\
\text { Handy- } \\
\text { Ag.194 } \\
\text {-s.S. }\end{array}$ & $\begin{array}{l}\text { Ca. } \\
\text { Colon, } \\
\text { Handy- } \\
\text { Ag.195 } \\
\text {-S.S. }\end{array}$ & & Typo & Amount & $\begin{array}{l}\text { Normal } \\
\text { Colon, } \\
\text { Haandy- } \\
\text { Ag.194 }\end{array}$ & $\begin{array}{l}\text { Ca. } \\
\text { Colon, } \\
\text { Handy- } \\
\text { Ag.195 }\end{array}$ \\
\hline $\begin{array}{r}\text { (A) } 1 \\
11 \\
14 \\
15 \\
16 \\
17 \\
18 \\
19 \\
20 \\
21\end{array}$ & 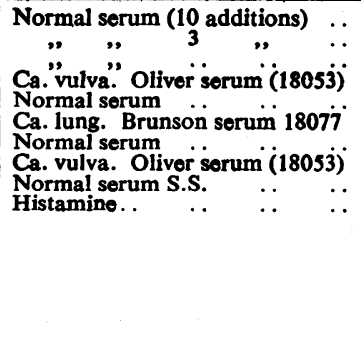 & $\begin{array}{l}. . \\
\because . \\
\because . \\
\because . \\
\because . \\
\cdots\end{array}$ & 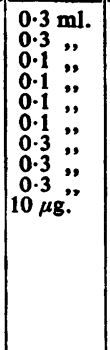 & $\begin{array}{l}\text { (2) } 1 \\
0 \\
0 \\
0 \\
0 \\
0 \\
0 \\
0 \\
0 \\
(7) \\
(7\end{array}$ & $\begin{array}{c}(15) 1 \\
(5) \\
(3) \\
(10) \\
0 \\
0 \\
(6) \\
0 \\
0 \\
0 \\
(15) \\
(*\end{array}$ & \begin{tabular}{|r|} 
(B) 1 \\
2 \\
3 \\
4 \\
13 \\
14 \\
15 \\
16 \\
17 \\
18 \\
19 \\
20 \\
21
\end{tabular} & 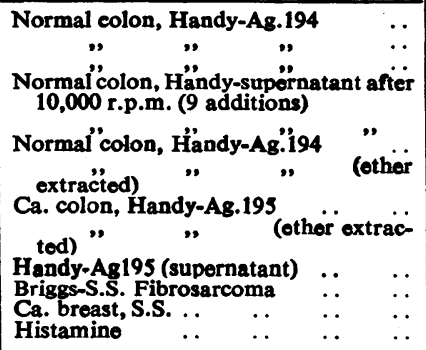 & 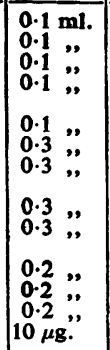 & $\begin{array}{c}0 \\
0 \\
0 \\
(20) \\
1 * \\
0 \\
0 \\
(2) 1^{*} \\
0 \\
0 \\
0 \\
0 \\
0 \\
(15) \\
1 *\end{array}$ & $\begin{array}{l}\text { (6) } 1 * \\
(3) 2^{*} \\
(2) 2 \\
(10) 1^{*} \\
0 \\
0 \\
(7) 1^{*} \\
0 \\
(5) 1 \\
(8) 1 \\
(7) 1 \\
0 \\
(12) 1^{*}\end{array}$ \\
\hline
\end{tabular}

Figures in parentheses represent the height of uterine contractions in mm. Figures 1 and 2 outside parentheses refer to the reaction taking place at the first or second half of the tracing. The asterisk designates a strong maintained reaction.

TABLE II.-Behaviour of Homologous and Autologous Tissue Antigens and Their Polysaccharide S.S. by the SchultzDale Method

\begin{tabular}{|c|c|c|c|c|c|c|c|c|c|c|c|c|c|c|c|}
\hline \multirow[b]{2}{*}{$\begin{array}{l}\text { Reac- } \\
\text { tion } \\
\text { No. }\end{array}$} & \multicolumn{5}{|c|}{ Reaction Released by } & \multicolumn{2}{|c|}{$\begin{array}{l}\text { Guinea-pigs } \\
\text { Immunized } \\
\text { with S.S. }\end{array}$} & \multirow{2}{*}{$\begin{array}{c}\text { Reac- } \\
\text { tion } \\
\text { No. }\end{array}$} & \multicolumn{5}{|c|}{ Reaction Released by } & \multicolumn{2}{|c|}{$\begin{array}{c}\text { Guinoa-pigs } \\
\text { Immunized } \\
\text { with Antigen }\end{array}$} \\
\hline & Type & & & & Amount & $\begin{array}{l}\text { Normal } \\
\text { Colon, } \\
\text { Handy- } \\
\text { Ag.194 } \\
\text { S.S. }\end{array}$ & $\begin{array}{l}\text { Ca. } \\
\text { Colon, } \\
\text { Handy-- } \\
\text { Ag.195 } \\
\text { S.S. }\end{array}$ & & Type & & & & Amount & $\begin{array}{l}\text { Normal } \\
\text { Kidney, } \\
\text { Ag.128 }\end{array}$ & $\begin{array}{c}\text { Acute } \\
\text { Lou- } \\
\text { kaemic } \\
\text { Kidney, } \\
\text { Ag.208 }\end{array}$ \\
\hline 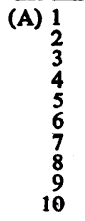 & $\begin{array}{l}\text { Normal serum donor } \\
\text { Ca. "stomach̆ (18385) } \\
\text { Ca. breast (18537) } \\
\text { Normal serum donor } \\
\text { Ca. lung (18245)... } \\
\text { Normal serum donor } \\
\text { Melanoma (18370) } \\
\text { Normal serum donor } \\
\text { Histamine.. ... }\end{array}$ & $\begin{array}{c}\because \\
\because \\
\cdots \\
\cdots \\
\cdots \\
\cdots\end{array}$ & $\begin{array}{l}\ldots \\
\cdots \\
\cdots \\
\cdots \\
\cdots \\
\cdots \\
\cdots\end{array}$ & $\begin{array}{l}\cdots \\
\cdots \\
\cdots \\
\cdots \\
\cdots \\
\cdots \\
\cdots\end{array}$ & 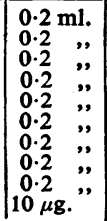 & \begin{tabular}{|c|c|}
0 \\
0 \\
$(1)$ & 1 \\
0 \\
0 \\
$(24)$ & $1 *$ \\
$(2)$ & 1 \\
$(18)$ & $2 *$ \\
0 & \\
$(26)$ & $1 *$
\end{tabular} & $\begin{array}{ll}\text { (2) } & 1 \\
(1) & 1 \\
(5) & 1 * \\
(18) & 1 * \\
(2) & 1 \\
(16) & 2 * \\
(5) & 1 \\
(20) & 1 * \\
(5) & 1 \\
(20) & 1 *\end{array}$ & $\begin{array}{r}\text { (B) } 1 \\
2 \\
3 \\
\text { to } 6 \\
7 \\
8 \\
8 \\
9 \\
10 \\
11 \\
12\end{array}$ & 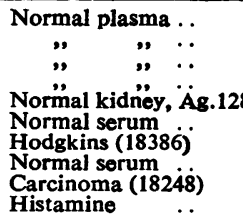 & $\begin{array}{l}\because \\
\therefore \\
\therefore 8 \\
\therefore \\
\therefore \\
\therefore\end{array}$ & $\begin{array}{l}. \\
\because \\
\because \\
\because \\
\because \\
\because \\
\cdots \\
\cdots\end{array}$ & $\begin{array}{l}\cdots \\
\cdots \\
\cdots \\
\cdots \\
\cdots \\
\cdots \\
\cdots\end{array}$ & 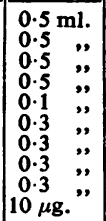 & 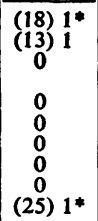 & $\begin{array}{c}(27) 1^{*} \\
(22) 1^{*} \\
(22) \\
0 \\
0 \\
(18) 1 \\
0 \\
(15) 2^{*} \\
0 \\
(31) 1^{*} \\
(31) 1^{*}\end{array}$ \\
\hline
\end{tabular}

\begin{tabular}{|c|c|c|c|c|c|c|c|c|c|c|c|}
\hline \multirow{2}{*}{$\underset{\text { tion }}{\text { Reac- }}$} & \multicolumn{3}{|l|}{ Reaction Roleased by } & \multicolumn{2}{|c|}{$\begin{array}{c}\text { Guinea-pigs } \\
\text { Immunized } \\
\text { with } \\
\text { Antigens }\end{array}$} & \multirow{2}{*}{$\begin{array}{c}\text { Reac- } \\
\text { tion }\end{array}$} & \multicolumn{3}{|l|}{ Reaction Reloased by } & \multicolumn{2}{|c|}{$\begin{array}{l}\text { Guinea-pigs } \\
\text { Immunjzed } \\
\text { with Ether. Ex- } \\
\text { tracted Antigens }\end{array}$} \\
\hline & Type & & Amount & $\begin{array}{l}\text { Normal } \\
\text { Colon, } \\
\text { Handy- } \\
\text { Ag.194 }\end{array}$ & $\begin{array}{l}\text { Ca. } \\
\text { Colon, } \\
\text { Handy- } \\
\text { Ag.195 }\end{array}$ & & Type & & Amount & $\begin{array}{l}\text { Normal } \\
\text { Colon, } \\
\text { Handy- } \\
\text { Ag.194E }\end{array}$ & $\begin{array}{c}\text { Ca. } \\
\text { Colon, } \\
\text { Handy- } \\
\text { Ag.195E }\end{array}$ \\
\hline (C) $\begin{array}{l}1 \\
2 \\
3 \\
4 \\
5 \\
6 \\
7\end{array}$ & 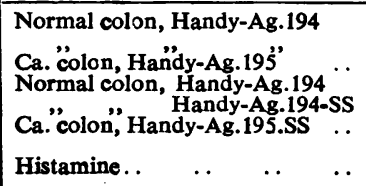 & $\begin{array}{l}\cdots \\
\cdots \\
\cdots \\
\cdots \\
\cdots \\
\cdots\end{array}$ & 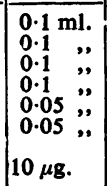 & $\begin{array}{c}(10) \\
0 \\
(1 * \\
0 \\
(1) \\
(2) \\
0 \\
0 \\
(23) \\
(23) \\
1 *\end{array}$ & $\begin{array}{cc}(18) & 1 * \\
0 & \\
(11) & 1 * \\
0 & \\
(8) & 1 \\
0 & \\
(21) & 1 * \\
(21) & 1 *\end{array}$ & $\begin{array}{r}\text { (D) } 1 \\
10 \\
11 \\
12 \\
13 \\
14\end{array}$ & 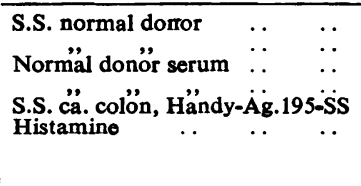 & $\begin{array}{l}\cdots \\
\cdots \\
\cdots \\
\cdots \\
\cdots\end{array}$ & $\begin{array}{l}0.5 \mathrm{ml} . \\
0.1 \quad ", \\
0.3 \quad ", \\
0.3 \quad ", \\
0.05, " \\
10 \mu \mathrm{g} .\end{array}$ & 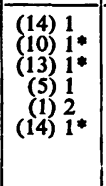 & $\begin{array}{c}\text { (4) } 1 \\
\text { (3) } 1 \\
\text { (15) } 1 * \\
0 \\
(10) 1^{*} \\
\text { (15) } 1 *\end{array}$ \\
\hline
\end{tabular}


Virgin female guinea-pigs are immunized, by the help of Freund's adjuvants, either with S.S. or with the original antigens obtained from neoplastic tissues. Control antigens and their corresponding S.S. are prepared from "normal" sections of the same organ from which the cancer tissue is obtained, and also from similar organs of a young healthy adult.

In three to four weeks the guinea-pigs are sacrificed and their uterine horns are used in a Schultz-Dale bath. Rabbits similarly immunized are bled and their sera used for passive in vitro or in vivo (intravenous) sensitization. To release the local in vitro anaphylactic reaction of the uterine muscle, various tissue antigens, their S.S. and P.L.S., are used, as well as sera from normal blood donors and from patients with cancer.

These reactions are recorded in $\mathrm{mm}$. in Tables $\mathrm{I}$ and II. In Table III results are shown in terms of contraction index (C.I.). This is the ratio of the specific contraction in $\mathrm{mm}$. to that resulting from $10 \mu \mathrm{g}$. of histamine base.

TABLe III.-Immunological Activity by the Schultz-Dale Method of a Polysaccharide-like Substance (P.L.S.) and Its Two Fractions $A$ and $B$ Prepared from Melanoma Antigen. (Results are Recorded in Terms of Contraction Index (C.I.). $0.1 \mathrm{ml}$. was Used to Release the Reaction)

\begin{tabular}{|c|c|c|c|}
\hline \multirow{2}{*}{$\begin{array}{l}\text { Reaction } \\
\text { No. }\end{array}$} & \multirow{2}{*}{$\underset{\text { by }}{\text { Reaction Released }}$} & \multicolumn{2}{|c|}{$\begin{array}{l}\text { Pigs Immunized with Melanoma Ag., } \\
\text { Sed. IIIB (3,000-10,000 r.p.m.) }\end{array}$} \\
\hline & & Horn A & Horn B \\
\hline $\begin{array}{l}1 \\
2 \\
3\end{array}$ & $\begin{array}{l}\text { Normal serum } \\
\text { Normal Ag. } \\
\text { Molanoma Ag. } \\
\text { Sed. IIIB } \\
\text { Fraction } O\end{array}$ & $\begin{array}{l}0 \\
0 \\
(0 \cdot 10) 2 *\end{array}$ & $\begin{array}{l}0 \\
0 \\
(0 \cdot 12) 2^{*}\end{array}$ \\
\hline $\begin{array}{l}4 \\
5 \\
6 \\
7\end{array}$ & $\begin{array}{l}\text { Melanoma Ag. } \\
\text { Sed. IIIB } \\
\text { Fraction A } \\
\text { Melanoma Ag. } \\
\text { Sed. IIIB } \\
\text { Fraction B }\end{array}$ & $\begin{array}{l}(1.0) 1 * \\
(0.73) 1^{*} \\
(0.25) 2^{*}\end{array}$ & $\begin{array}{l}(0.87) 1^{*} \\
(0.87) 1^{*} \\
(0.36) 2^{*}\end{array}$ \\
\hline 8 & $\begin{array}{l}\text { Melanoma Ag. } \\
\text { Supornatant } \\
10,000 \text { r.p.m. }\end{array}$ & $(0.87) 2 *$ & $(0.91) 2^{*}$ \\
\hline 9 & Histamine (10 r) & $(1 \cdot 0) 1^{*}$ & $(1.0) 1 *$ \\
\hline
\end{tabular}

\section{Results}

In general, the same result is obtained from guinea-pigs immunized with both S.S. and the original antigens. Furthermore, S.S., P.L.S., and original antigens release the SchultzDale reactions equally well.

In fact, the polysaccharide-like fractions, $A$ and $B$, give a higher contraction index than does the original melanoma antigen (fraction $O$ ), fraction $A$ giving the highest figures (see Table III). Desensitization is possible with these reactions.

Some typical reactions are shown in Tables I and II. After desensitization to normal serum and normal tissue antigens, the uterine horns from the cancer-immunized guinea-pigs still react positively in response to sera or tissue antigens from carcinoma or related tumours. Table I shows this phenomenon clearly. Thus, in Table I,A the uterine horns of guinea-pigs immunized to S.S. carcinoma of the colon (Ag.-SS.195 (Handy)) reacted specifically (after desensitization to normal serum in reactions A1 to A14) with sera from carcinoma patients (reactions A15 and A17), but not with sera from normal donors (reactions A16 and A18). On the other hand, control uterine horns of guinea-pigs immunized to S.S. " normal " colon (Ag.-SS.194 (Handy)) did not react to these same sera from carcinoma patients or from normal donors (after desensitization to normal serum).

The immunological specificity of these positive reactions is strongly suggested by desensitization procedures in which the sensitized uterine horns initially exposed to a positive reacting serum or a tissue antigen fail to react to the same antigen after these horns are washed and exposed again. This indicates specific neutralization of antibodies fixed to the horn by their specific antigens and excludes the possibility of a non-specific pressor effect. For example, Table I shows a marked reaction to serum from carcinoma case 18053 in A15; a weaker reaction to serum from another carcinoma, 18077, in A17 ; and no reaction at all on second contact with carcinoma serum, 18053, in A19.

Table I,B shows a similar behaviour of the uterine muscles from guinea-pigs immunized to the native original antigens -that is, carcinoma of the colon (Ag.195 (Handy)) and "normal" colon (Ag.194 (Handy)), as was shown for their S.S. counterpart. In addition, the comparative strength of various antigens in releasing the reaction is shown. Ether extraction of antigens 194 and 195, for example, improved their antigenicity, as shown by their ability to release the reaction in the Schultz-Dale bath (Table I,B, 14, 15, 16, and 17). Furthermore, the capacity of these antigens to immunize guinea-pigs was well preserved even after their ether extraction (Table II,D). It is also apparent that after centrifuging at 10,000 r.p.m. the supernatant fraction of the antigen is much more effective in releasing the reaction than the sediment even when the latter is ether extracted (see Table I,B : $3,4,16,17$, and 18).

Table II further reveals the parallel behaviour of S.S. and of original antigen. It also shows the behaviour of autologous antigens (wherein neoplastic and "normal" tissues are taken from the same patient) as compared with homologous antigens (wherein the neoplastic and the control normal tissues are taken from a carcinoma patient and from a healthy accident victim respectively). In the case of autologous antigens the so-called "normal" tissue is not altogether normal immunologically. Although it shows mostly normal tissue components for the most part when the full antigen is used for immunization of guinea-pigs (Table II,C, 1 and $5 ; \mathrm{D}, 1$ to 12), it does show carcinoma components when S.S. is used for immunization (Table II,A, 6 and 8 ) and for releasing the reaction (Table II,C, 5 and 6). In the latter case both "normal" colon (Ag.194-S.S. (Handy)) and carcinoma of the colon (Ag.195-S.S. (Handy)) possess the same abnormal components although they are present to a lesser degree in the "normal" tissue. Furthermore, desensitization indicates that these abnormal components are antigenically similar to the carcinoma antigen. Thus we see that prior addition of "normal" colon (Ag.194-S.S. (Handy)) to the carcinoma horn (Table II,C, 5) desensitized it completely to further addition of carcinoma of the colon (Ag.195-S.S. (Handy)). However, the same amount of Ag.195-S.S. did react specifically with another similarly sensitized horn (Table II,D, 13). This was not the case, however, when autologous tissue antigens were used from a healthy person. This is shown by Table II,B, in which tissue antigens are prepared from the kidney of a patient with acute leukaemia and control antigens are prepared from the kidney of a young victim of a car accident. Only normal tissue antigens were found in the healthy kidney.

The common antigenicity between various types of malignant tumours is shown in Table I,A, 15 and 17 ; between fibrosarcoma and carcinoma in Table I,B, 19 and 20 ; between various types of carcinomas and melanomas in Table II,A, 3, 4, 6, and 8; and between leukaemia, Hodgkin's disease, and carcinoma in Table II,B, 9 and 10 . This aspect will be studied in other articles (Makari, 1958a, 1958b).

\section{Discussion}

The immunologically active substances in the serum and tissues of cancer patients behave like polysaccharides when studied by the Schultz-Dale test. They are precipitated by isopropyl alcohol, and their activity is maintained, and even improved, after deproteinization with chloroform and butyl alcohol. Burrows and Neill (1958) showed that acid hydrolysis resulted in complete loss of activity. This does not contradict the polysaccharide nature of these antigens, since acid hydrolysis of polysaccharides is known to destroy their antigenicity. Extraction with $2 \mathrm{~N} \mathrm{NaOH}$, however, hydrolyses 
the bonds between carbohydrates and proteins (Meyer and Rapport, 1951), while heat to $100^{\circ} \mathrm{C}$. denatures the proteins. This probably explains why treatment with heat and alkalis does not destroy their ability to immunize guineapigs or to release the Schultz-Dale reaction. The fact that such activity persists after ether extraction tends to refute the lipid nature of cancer antigens. The slight improvement in antigenicity resulting from ether extraction is again consistent with a polysaccharide nature, since polysaccharides have a great affinity for lipids.

Moreover, the polysaccharide nature of the antigen explains the greater activity of the supernatant, as compared with the sediment, in releasing the Schultz-Dale reaction. The less soluble and less active components are probably the result of gradual drying of tissues. This, according to Whistler and Smart (1953), occurs when highly hydrated polysaccharide material is air-dried. The gradual removal of water molecules allows neighbouring polysaccharide molecules to come together and establish strong bonds which later restrain the separation of molecules. This reduction in surface area and in the number of active available sites on the polysaccharide molecules could be regarded as a form of polymerization, and would account for the in vitro reduction of antigenic activity - that is, its capacity to release the reaction in the Schultz-Dale bath-of the sediment as compared with the supernatant.

These studies also raise the question of the relatively "normal " nature of the healthy colon tissue obtained from the patient Handy, who did have a carcinoma of the colon. Is pathologically " normal" tissue necessarily immunologically "normal"? Is the better control tissue to use in this case " normal" colon from the same patient or from a young healthy accident case ?

The above findings indicate the presence of the specific carcinoma polysaccharide-like antigens in these so-called "normal" portions from the carcinoma patients, although to a less extent than in the neighbouring neoplastic tissue. They also indicate that this soluble polysaccharide-like antigen is present not only in the cancerous tissue but also in the blood and other tissues, even those that appear pathologically "normal." This was the reason for the use in later studies of homologous tissues from a healthy individual rather than from the cancer patient himself.

The polysaccharide nature of cancer antigens could easily explain why mast cells and tissue polysaccharides are the predominating elements in the development and growth of connective-tissue tumours as shown by Sylvén (1945), Holmgren and Wohlfart (1947), and Gersh and Catchpole (1949). It could also explain the greatly increased amounts of polysaccharides always found in the serum of cancer patients. Furthermore, it throws new light on the finding of high levels of hyaluronidase inhibitors in the blood of patients with disseminated cancer by Kiriluk et al. (1950) and with certain leukaemias and lymphomas by Hentstell and Freedman (1951).

The association of polysaccharides with polypeptides is well known. Morgan (1941) and Partridge and Morgan (1942), for example, were able to make artificial complexes using "polypeptide-like" substances isolated from Shiga, and carbohydrates such as group A substance from commercial pepsin. It was found that these "polypeptide-like" substances appear to have a special power to form antigenic complexes with polysaccharides.

It is our belief that the activity of the polypeptide found by Burrows and Neill (1958) in the serum of cancer patients is due to an associated polysaccharide antigen. The finding by Winzler (1953), referred to by Burrows and Neill, of an increase in polypeptides in the serum in carcinoma, and specifically of mucopolypeptides, strengthens this possibility.

Polysaccharides are less complex to study immunochemically than are proteins. This finding, therefore, of the polysaccharide nature of cancer antigens should give us a little more reason for optimism in our attempts to understand the cancer problem and a greater hope of its solution.

These results are preliminary in nature, and work along these lines is being continued at the Muhlenberg Hospital. Further evidence for the polysaccharide nature of cancer antigens, using another immunological technique, will be published elsewhere.

\section{Summary}

Substances distinctly polysaccharide-like in nature have been prepared from cancer and normal tissue antigens by two procedures: (1) by precipitation with isopropyl alcohol and deproteinization with chloroform and butyl alcohol (P.L.S.) ; and (2) by heat and alkali treatment (S.S.).

The specific immunological activity of cancer antigens seems to reside in these polysaccharide-like substances.

I thank Mr. H. D. Hamilton, of the Muhlenberg Hospital, for his help in preparing the nanuscript. This work was done at the University of Texas.

\section{REFERENCES}

Burrows, D. (1958). Brit. med. J., 1, 368.

$\bar{C}$ and Neill, D. W. (1958); Ibid., 1, 370.

Chang, S. (1953). J. Immunol., 70, 212.

Gen Snyder, J. C., and Murray, E. S. (1953). Ibid., 70, 215

Gersh, I., and Catchpole, H. R. (1949). Amer. J. Anat., 85, 457.

Hentstell, H. H. Bol. (N.Y.), 76, 239

Holmgren, H., and Wohlfart, G. (1947). Cancer Res., 7, 686

Kiriluk, L. B., Kremen, A. J., and Glick, D. (1950). 'J. nat. Cancer Inst., $10,993$.

Makari, J. G. (1955a). Amer. J. Path., 31, 581.

- (1955b). Brit. med. J., 2, 1291.

- (1958á). Ibid., 2, 358 .

Meyer, K., and Rapport, M. M. (1951). Science, 113, 596.

1)

Partridge, S. M., and Morgan, W. T. J. (1942). Brit. J. exp. Path., 23, 84 Sylvén B (1945) and radiol. (Stockh) Suppl 59. Wylvén, B. (1945). Acta radtol. (Stockh.), Suppl. S9.

Winzler, R. J. (1953). Advanc. Cancer Res., 1, 503.

\section{DETECTION OF ANTIGENS IN SERA OF PATIENTS WITH NEOPLASTIC DISEASE BY SCHULTZ-DALE TEST \\ ITS POSSIBLE USE AS A SCREENING PROCEDURE FOR TUMOURS}

BY

JACK G. MAKARI, M.D., D.T.M.\&H., Sc.M. Research Department, Muhlenberg Hospital, Plainfield, New Jersey, U.S.A.

In search of a specific diagnostic serological test in cancer we have looked for a high degree of positive results in known cancer cases and a high degree of negative results in non-cancerous disease. Dunn and Greenhouse (1951) tentatively set limits of $90 \%$ accuracy in cases of cancer and $95 \%$ accuracy for patients with non-cancerous disease.

Makari (1955) described the use of the Schultz-Dale test for the detection of carcinoma antigen in the serum of patients with carcinoma. It was shown that, when the carcinoma antigen used for immunization of guinea-pigs was the sediment obtained between 3,200 and 4,000 r.p.m., this test would conform to the criteria set up by Dunn and Greenhouse-that is, it was positive in $96.8 \%$ of proved carcinoma cases and negative in $95.2 \%$ of non-cancerous lesions.

Recently Burrows (1958) was able to confirm our results in a large series of 508 patients, and recorded an accuracy of $96.7 \%$ in proved carcinoma cases and of $96.7 \%$ in non-cancerous lesions. This establishes the 